Florida State University College of Law

Scholarship Repository

Scholarly Publications

1982

Sex-Based Wage Discrimination Under the Title VII Disparate

Impact Doctrine

Mark B. Seidenfeld

Follow this and additional works at: https://ir.law.fsu.edu/articles

Part of the Constitutional Law Commons

Recommended Citation

Mark B. Seidenfeld, Note, Sex-Based Wage Discrimination Under the Title VII Disparate Impact Doctrine, 34 Stan. L. Rev. 1083 (1982).

This Article is brought to you for free and open access by Scholarship Repository. It has been accepted for inclusion in Scholarly Publications by an authorized administrator of Scholarship Repository. For more information, please contact efarrell@law.fsu.edu. 


\section{Sex-Based Wage Discrimination Under the Title VII Disparate Impact Doctrine}

Both the Equal Pay Act of $1963^{1}$ and Title VII of the Givil Rights Act of $1964^{2}$ prohibit sex-based wage discrimination. The Equal Pay Act prohibits an employer from paying unequal wages to men and women who do work of substantially "equal skill, effort, and responsibility."3 Title VII prohibits employers from discriminating on the basis of "race, color, religion, sex, or national origin."4 Courts interpreting Title VII have permitted plaintiffs to establish claims by showing either disparate treatment ${ }^{5}$ or disparate impact. ${ }^{6}$

1. 29 U.S.C. $\S 206(d)$ (1976); see note 3 infra.

2. 42 U.S.C. $\S \S 2000$ e to $2000 \mathrm{e}-17$ (1976 \& Supp. III 1979). For the text of the pertinent provisions, see notes 4,13 \& 15 infra.

3. 29 U.S.C. $§ 206$ (d)(1) (1976) ("No employer . . . shall discriminate . . . on the basis of sex by paying wages to employees. . . at a rate less than the rate at which he pays wages to employees of the opposite sex . . . for equal work on jobs the performance of which requires equal skill, effort, and responsibility, and which are performed under similar working conditions...." .").

For a discussion of the doctrine, see Hodgson v. American Bank of Commerce, 447 F.2d 416, 420 (5th Cir. 1971); Schultz v. Wheaton Glass Co., 421 F.2d 259, 265 (3d Cir.), cert. denied, 398 U.S. 905 (1970). On when jobs are substantially equal, see Brennan v. Owensboro-Daviess County Hosp., 523 F.2d 1013 (6th Cir. 1975) (catheterization of male patients, a duty performed by orderlies about twice a week, did not justify paying orderlies more than nurses: a "pay differential cannot be justified on the basis of the occasional extra work"), cert. denied, 425 U.S. 973 (1976); Brennan v. Prince William Hosp. Corp., 503 F.2d 282 (4th Cir. 1974) (similar facts), cert. denied, 420 U.S. 972 (1976); $c f$. Gunther v. County of Washington, 623 F.2d 1303, 1310 (9th Cir. 1979) (holding that male and female guards at a county jail did not perform substantially equal work because each man guarded 10 times the number of prisoners that each women guarded and because women performed substantial clerical duties), affd on other grounds, 452 U.S. 161 (1981).

4. 42 U.S.C. $\S 2000 \mathrm{e}-2$ (a) (1976) ("It shall be an unlawful employment practice for an employer-(1) to fail or refuse to hire or to discharge any individual, or otherwise to discriminate against any individual with respect to his compensation, terms, conditions, or privileges of employment, because of such individual's race, color, religion, sex, or national origin; or (2) to limit, segregate, or classify his employees or applicants for employment in any way which would deprive or tend to deprive any individual of employment opportunities or otherwise adversely affect his status as an employee, because of such individual's race, color, religion, sex, or national origin.").

5. Disparate treatment claims require proof that an employer intentionally discriminated against women. An employer intentionally discriminates if he uses sex as a factor in an employment decision. See International Bhd. of Teamsters v. United States, 431 U.S. 324, 335 n.15 (1977) ("The employer simply treats some people less favorably than others because of 
Until 1980, courts did not apply Title VII standards to sex-based wage discrimination; instead, they had interpreted the Bennett Amendment to Title $\mathrm{VII}^{7}$ to require plaintiffs to show a violation of the Equal Pay Act's equal pay for equal work standard. ${ }^{8}$ In County of Washington v. Gunther, ${ }^{9}$ the Supreme Court held that the Bennett Amendment incorporates into Title VII the four affirmative defenses of the Equal Pay Act, ${ }^{10}$ but not the unequal pay for equal work requirement. Treating the case as one of disparate treatment, the Court did not discuss whether the Bennett Amendment precludes all disparate impact claims of sex-based wage discrimination. The Court also declined to address whether unequal pay for jobs of "comparable worth" violates Title VII. ${ }^{11}$ This note argues that courts should permit disparate impact claims of sex-based wage discrimination, but deny disparate impact claims based on evidence of comparable worth.

their . . . sex . . . . Proof of discriminatory motive is critical, although it can in some situations be inferred from the mere fact of differences in treatment.").

6. Disparate impact claims do not require proof of intent, and reach practices which, although facially neutral, operate adversely to affect women. See Dothard v: Rawlinson, 433 U.S. 321, 328-31 (1977) (applying the disparate impact doctrine to sex discrimination and holding that statutory height and weight requirements for prison guards, although facially neutral, violate Title VII; International Bhd. of Teamsters v. United States, 431 U.S. 324, 335 n.15 (1977); Griggs v. Duke Power Co., 401 U.S. 424, 430-32 (1971).)

7. 42 U.S.C. $\S 2000 \mathrm{e}-2(\mathrm{~h})(1976)$; see note 13 infra.

8. See, e.g., Laffey v. Northwest Airlines, Inc., 567 F.2d 429 (D.C. Cir. 1976); Calage v. University of Tenn., 544 F.2d 297 (6th Cir. 1976); Orr v. Frank R. MacNeill \& Son, Inc., 511 F.2d 166 (5th Cir.), cert. denied, 423 U.S. 865 (1975); Ammons v. Zia Co., 448 F.2d 117 (10th Cir. 1971).

\section{452 U.S. 161 (1981).}

10. 29 U.S.C. $\$ 206$ (d)(1) (1976); see note 14 infra and accompanying text.

11. A "comparable worth" claim means a claim based on evidence that workers in "female" jobs earn less than workers in "male" jobs that require comparable skill, effort, and responsibility. For example, since most secretaries (99\%) are female and most mail clerks (79\%) are male, BuREau OF LABOR Statistics, U.S. DeP'T OF LABOR, PERSPectives ON WORKING WOMEN: A DATEBOOK 10 (1980), proof that the skill, effort, and responsibility of a secretary exceeds that of a mail clerk by $25 \%$ and that a particular employer paid secretaries, on the average, the same wages as mail clerks would state a comparable worth case.

For a discussion of comparable worth, see generally, COMMITTEE ON OCCUPATIONAL Classification \& ANAlysis, National Research Council, WOMEn, WORK aNd Wages: EQUAL PAY FOR JOBS OF EQUAL VALUE (1981) [hereinafter cited as WOMEN, WORK, AND WAGES]; COMPARABLE WORTH, IsSUES AND Alternatives (E. Livernash ed. 1980); Blumrosen, Wage Discrimination, Job Segregation, and Title VII of the Civil Rights Act of 1964, $12 \mathrm{U}$. MiCH. J.L. REF. 397, 428-57 (1979); Gasaway, Comparable Worth: A Post-Gunther Overview, 69 Geo. L.J. 1123 (1981); Gitt \& Gelb, Beyond the Equal Pay Act: Expanding Wage Differential Protections Under Title VII, 8 LoY. U. CHI. L.J. 723, 723-59 (1977); Nelson, Opton \& Wilson, Wage Discrimination and the "Comparable Worth" Theory in Perspective, 13 U. Mich. J.L. REF. 231 (1980) (responding to Blumrosen, supra); Note, Equal Pay, Comparable Work, and Job Evaluation, 90 YALE L.J. 657 (1981); Comment, Sex-Based Wage Discrimination Claims After County of Washington v. Gunther, 81 CoLUM. L. REV. 1333 (1981). 
Part I of this note sketches the contours of Title VII wage discrimination law prior to and including Gunther. Part II argues that disparate impact doctrine should apply to sex-based wage discrimination. Part III argues that Title VII doctrine should not be extended to include comparable worth claims because such claims, unlike traditional disparate impact claims, conflict with the policies underlying Title VII.

\section{Wage Discrimination Proscription Under Title VII}

The Bennett Amendment ${ }^{12}$ attempts to reconcile conflicts between the Equal Pay Act and Title VII by making it lawful under Title VII "for any employer to differentiate upon the basis of sex . . . if such differentiation is authorized by the [Equal Pay Act]."13 The Equal Pay Act, however, does not "authorize" any conduct; rather, it prohibits unequal pay for equal work, and provides four affirmative defenses to the equal pay requirements. Once a plaintiff has demonstrated unequal pay for equal work, an employer may escape liability by proving that any pay difference is due to "(i) a seniority system; (ii) a merit system; (iii) a system which measures earnings by quantity or quality of production; or (iv) . $\therefore$. any other factor other than sex...."14 Title VII explicitly provides an employer with only the first three of these four defenses. ${ }^{15}$

Until 1980, courts required Title VII plaintiffs bringing a sexbased wage discrimination case to prove unequal pay for equal work. ${ }^{16}$ But the equal pay for equal work standard did little to im-

12. 42 U.S.C. $\$ 2000 \mathrm{e}-2(\mathrm{~h})(1976)$. The Bennett Amendment is one of two exceptions to coextensive treatment of race and sex. The other exception permits sex-based discrimination when sex is a "bona fide occupational qualification." 42 U.S.C. $\$ 2000 \mathrm{e}-2$ (e) (1976).

13. 42 U.S.C. $\$ 2000 \mathrm{e}-2(\mathrm{~h})(1976)$. The full text of the amendment reads: "It shall not be an unlawful employment practice under this subchapter for any employer to differentiate upon the basis of sex in determining the amount of wages or compensation paid or to be paid to employees of such employer if such differentiation is authorized by the [Equal Pay Act]."

14. 29 U.S.C. $\S 206$ (d)(1) (1976).

15. 42 U.S.C. $\$ 2000 \mathrm{e}-2(\mathrm{~h})$ (1976) ("it shall not be an unlawful employment practice for an employer to apply different standards of compensation, or different terms, conditions, or privileges of employment pursuant to a bona fide seniority or merit system, or a system which measures earnings by quantity or quality of production ...., provided that such differences are not the result of an intention to discriminate because of race, color, religion, sex, or national origin").

16. See, e.g., Di Salvo v. Chamber of Commerce, 568 F.2d 593 (8th Cir. 1978); Orr v. Frank R. MacNeill \& Son, Inc., 511 F.2d 166 (5th Cir.), cert. denied, 423 U.S. 865 (1975); Ammons v. Zia Co. 448 F.2d 117, 120 (10th Cir. 1971). The development of this line of cases stems, strangely enough, from Schultz v. Wheaton Glass Co., 421 F.2d 259, 266 (3d Cir.), cert. denied, 398 U.S. 905 (1970), an Equal Pay Act case which expanded the notion of equal work to include "substantially equal" work, in order to harmonize the Equal Pay Act with Title VII. 
prove women's wages relative to those of men. ${ }^{17}$ The equal work requirement would insulate employers from liability where discrimination occurs because men predominately staff high-paying jobs, thereby relegating women to lower-paying positions. Employers were free to use factors in setting wages which would have been illegal under Title VII had they been used to determine any other condition of employment. Employers were even free to intentionally discriminate-to decrease wages for jobs because those jobs were staffed predominately by women. ${ }^{18}$

In County of Washington $v$. Gunther, ${ }^{19}$ the Supreme Court, in a 5-4 decision, affirmed recent lower court decisions incorporating into Title VII the four defenses of the Equal Pay Act. ${ }^{20}$ In Gunther, female guards in the female section of the Washington County jail were paid only $70 \%$ as much as male guards, even though the County had determined that their jobs were worth $95 \%$ as much as the jobs of male guards guarding male prisoners. ${ }^{21}$ The plaintiffs had lost in district court on a claim that their jobs were substantially equal to those of male guards. ${ }^{22}$ They claimed that Washington County nevertheless had violated Title VII by intentionally depressing the female guards' wages. $^{23}$

Justice Brennan, writing for the majority, interpreted both the language and legislative history of the Bennett Amendment to incorporate into Title VII the four affirmative defenses of the Equal Pay

The Tenth Circuit, in Ammons, 448 F.2d at 120, incorrectly cited Wheaton Glass for the proposition that a wage discrimination suit under Title VII requires a showing of unequal pay for equal work. Subsequent cases generally cited $A m m o n s$ as stating the law on this point, e.g., $D i$ Salvo, 568 F.2d at 596; Orr, 511 F.2d at 171.

17. Since the passage of Title VII, wages of women have remained near $60 \%$ of men's wages. See, WOMEN, WORK, AND WAGES, supra note 11, at 14, 16. This earnings gap is not explained by age, number of years worked, education, or any other identified factor. See id. at 15-24; Levitan, Quinn \& Staines, Sex Discrimination Against the American Working Women, 15 Am. Behav. Sci. 237 (1971). See generally B. Babcock, A. Freeman, E. NorTon \& S. Ross, Sex Discrimination and the LAW: Causes and Remedies 192-217 (1975); Blumrosen, supra note 11; Gitt \& Gelb, supra note 11.

18. See International Union of Elec. Workers v. Westinghouse Elec. Corp., 631 F.2d 1094, 1100 (3d Cir. 1980), cert. denied, 449 U.S. 1009 (1981).

19. 452 U.S. 161 (1981).

20. The Court was affirming the decisions of three courts of appeals. See International Union of Elec. Workers v. Westinghouse Elec. Corp., 631 F.2d 1094 (3d Cir. 1980), cert. denied, 449 U.S. 1009 (1981); Fitzgerald v. Sirloin Stockade, Inc., 624 F.2d 945 (10th Cir. 1980); Gunther v. County of Washington, 623 F.2d 1303 (9th Cir. 1979).

21. 452 U.S. at 180.

22. 623 F.2d at 1310 (noting that male guards guarded 10 times as many prisoners per guard as did female guards, and that female guards did considerable clerical work). The plaintiffs did not raise this claim in the Supreme Court. 452 U.S. at 165.

23. 452 U.S. at 165 . 
Act but not the unequal pay for equal work requirement. ${ }^{24} \mathrm{He}$ found further support for this conclusion in the broad remedial purposes of Title VII, which require the Court to "avoid interpretations of Title VII that deprive victims of discrimination of a remedy, without clear congressional mandate."25 But Justice Brennan explicitly refused to discuss the effect of the fourth Equal Pay Act defensethat an employer can escape liability if the pay difference is due to any "factor other than sex" - on Title VII litigation. ${ }^{26}$

Incorporation of the fourth defense will not affect proof of intent under the disparate treatment doctrine. ${ }^{27}$ But whether the fourth defense bars disparate impact claims of sex-based wage discrimination remains unclear. ${ }^{28}$ Similarly, the narrower but practically more important question whether proof of unequal pay for jobs of comparable worth states a disparate impact claim remains undecided. ${ }^{29}$

24. Id. at 168-76. The majority viewed the Bennett Amendment as designed to avoid statutory conflicts that might arise due to congressional oversight rather than to address a specific statutory conflict. Id. at 174-75. The legislative history, though not unambiguous, supports this interpretation. See 110 CoNG. REC. 13,647 (1964) (remarks of Senators Bennett and Dirksen, referring to the amendment as a "technical correction" to provide that "in the event of conficts, the provisions of the Equal Pay Act shall not be nullified") (emphasis added); County of Washington v. Gunther, 452 U.S. 161, 171-75 (1981) (discussing the legislative history of the Bennett Amendment). But of. id. at 189-90 (Rehnquist, J., dissenting) (the Bennett Amendment incorporates into Title VII the entire Equal Pay Act standard).

25. 452 U.S. at 178. Justice Rehnquist, in dissent, argued that "Congress balanced the need for a remedy for wage discrimination against its desire to avoid the burdens associated with government intervention into wage structures" when it passed Title VII. Id. at 203.

26. 452 U.S. at 171.

27. The fourth defense-permitting wage differentials due to "any other factor other than sex"-does not shield from liability employers who intentionally discriminate, because intentional discrimination means using sex as a factor. See note 5 supra. Title VII's affirmative defenses are explicitly available only if employment differences between men and women "are not the result of an intention to discriminate." 42 U.S.C. $\$ 2000 \mathrm{e}-2(\mathrm{~h})$ (1976). The Equal Pay Act defenses are not explicitly subject to this proviso, but courts require that the seniority, merit, and quantity or quality of work defenses must not be pretexts for intentional sex discrimination. See EEOC v. Aetna Ins. Co., 616 F.2d 719, 725 (4th Cir. 1980); Brennan v. Victoria Bank \& Trust Co., 493 F.2d 896, 901 (5th Cir. 1974).

28. Cf. Note, Age Discrimination and the Disparate Impact Doctrine, 34 STAN. L. REv. 837 (1982) (arguing that a "reasonable factors other than age" defense to an age discrimination suit under the Age Discrimination in Employment Act, 29 U.S.C. §623(f)(1) (1976), bars disparate impact suits).

29. 452 U.S. at $166,180-81$. Justice Brennan carefully noted that the plaintiffs' claim did not require the Court "to make its own subjective assessment of the value of the male and female guard jobs, or attempt by statistical technique or other method to quantify the effect of sex discrimination on wage rates." Id. at 181. This dicta hints that comparable worth claims go beyond Title VII's ambit. 


\section{Disparate Impact Applied To Wage Discrimination}

Title VII disparate impact doctrine prohibits employment practices which disproportionately disadvantage women unless those practices are sufficiently job-related to meet the "business necessity" defense. ${ }^{30}$ Once the plaintiff demonstrates that a particular employment practice disproportionately affects women, ${ }^{31}$ the burden shifts to the defendant to show that the practice in question is "job related. ${ }^{132}$ If the employer satisfies this burden, the plaintiff may then show that "other employment practices without a similar discriminatory effect would also 'serve the employer's legitimate interest in "ef-

30. The Supreme Court first articulated the disparate impact doctrine in Griggs v. Duke Power Co., 401 U.S. 424 (1971) (an employment test which disqualifies a greater percentage of black job applicants than white job applicants violates Title VII). The Court extended the doctrine to sex discrimination in Dothard v. Rawlinson, 433 U.S. 321 (1977) (invalidating minimum height and weight requirements for prison guard positions). For a general discussion of disparate impact theory, see Perry, The Disproportionate Impact Theory of Racial Discrimination, 125 U. PA. L. REV. 540 (1977).

31. Plaintiffs can prove disparate impact by focusing on the actual job applicants or employees affected, see, e.g., Griggs v. Duke Power Co., 401 U.S. 424, 430 n.6 (test disqualified $42 \%$ of white job applicants and $94 \%$ of black job applicants); Vulcan Soc'y of the New York City Fire Dep't v. Civil Serv. Comm'n, 490 F.2d 387, 392 (2d Cir. 1973), or by demonstrating the potential impact on women in general, see, e.g., Dothard v. Rawlinson, 433 U.S. 321, 329-30 (plaintiffs made a prima facie disparate impact case because the minimum height requirement in question would have excluded $33.29 \%$ of women in the United States and only $1.28 \%$ of men); Griggs, 401 U.S. at 430 \& n.6 (rejecting a high school diploma requirement because $34 \%$ of white males in North Carolina, but only $12 \%$ of black males, had completed high school).

One court has stated, in dicta, that a plaintiff may make a prima facie disparate impact claim in a third way-by comparing the composition of the defendant's work force with that of the appropriate labor market. Green v. Missouri Pac. R.R., 523 F.2d 1290, 1294 (8th Cir. 1975). A gross disparity between the composition of the work force and the labor market, although not sufficient under the disparate impact doctrine, may suffice to create a prima facie disparate treatment claim. See Hazelwood School Dist. v. United States, 433 U.S. 299, 307-08 (1977); International Bhd. of Teamsters v. United States, 431 U.S. 324, 335 n.15, 339 n.20 (1977).

32. Dothard v. Rawlinson, 433 U.S. 321 (1977). Recently some lower courts, citing Texas Dep't of Community Affairs v. Burdine, 450 U.S. 248 (1981), have stated that the defendant's burden in a disparate impact case is merely to present evidence of job-relation, but that at all stages the plaintiff has the burden of proving discrimination. See NAACP v. The Medical Center, Inc., 657 F.2d 1322 (3d Cir. 1981) (en banc); Kouba v. Allstate Ins. Co., 523 F. Supp. 148, 154 (E.D. Cal. 1981) (dicta). But Burdine simply reiterated the existing allocation of burdens of proof in disparate impact cases. See Board of Trustees of Keene State College v. Sweeney, 439 U.S. 24 (1978); Furnco Constr. Corp. v. Waters, 438 U.S. 567 (1978); McDonnell Douglas Corp. v. Green, 411 U.S. 792 (1973). Most courts recognize that disparate impact claims "are unaffected by the Supreme Court ruling in Burdine." Heffernan v. Western Elec. Co., 510 F. Supp. 712 (N.D. Ga. 1981); see also Johnson v. Uncle Ben's, Inc., 657 F.2d 750, 752 (5th Cir. 1981) ("Burdine . . . does not address Title VII disparate impact cases"). 
ficient and trustworthy workmanship." , ',33

\section{A. Applying the Disparate Impact Doctrine to Sex-Based Wage Discrimination}

The disparate impact doctrine furthers a number of social purposes. ${ }^{34}$ In the abstract, these purposes fully support applying disparate impact doctrine to sex-based wage discrimination.

First, disparate impact doctrine aids in eliminating covert intentional discrimination. ${ }^{35}$ Proof of intent, like proof of any state of mind, is difficul ${ }^{36}$ since employers can hide discriminatory intent behind a screen of facially neutral factors. The only.evidence of discrimination may be the wage disparity these factors cause.

Second, disparate impact doctrine furthers the social policy of alleviating present harm due to past individual or societal discrimination. ${ }^{37}$ Prior to the adoption of Title VII, employers often intentionally depressed women's wages, and because of sex-segregation in the workplace never had to appropriately increase these

33. Johnson v. Uncle Ben's, Inc., 657 F.2d 750, 753 (quoting Dothard v. Rawlinson, 433 U.S. 321, 329 (1977) (citations omitted)).

34. See Brest, The Supreme Court 1975 Term-Foreword: In Defense of the Antidiscrimination Principle, 90 HARv. L. REv. 1, 22-54 (1976); Fiss, $A$ Theory of Fair Employment Laws, 38 U. CHI. L. Rev. 235, 244-49, 296-304 (1971); Freeman, Legitimizing Racial Discrimination Through Antidiscrimination Law: A Critical Review of Supreme Court Doctrine, 62 MINN. L. REv. 1049 (1978); Perry, supra note 30 .

35. See, e.g. , Brest, supra note 34 , at 26 ; Fiss, supra note 34 , at 296 . The need to check covert sexual discrimination may exceed the need to prevent covert racial discrimination because society is more likely to accept employment decisions based on physical differences between men and women, see, e.g. , Gerdom v. Continental Airlines, Inc., 648 F.2d 1223, 1227 (9th Gir. 1981) (an employer "may have different weight requirements for men and women of the same height to take account of physiological differences between sexes"); Longo v. Carlisle DeCoppett \& Co., 537 F.2d 685 (2d Cir. 1976) (employers may adopt different hair grooming requirements for men and women); Willingham v. Macon Tel. Publishing Co., 507 F.2d 1084 (5th Cir. 1975) (en banc) (same), than decisions based on differences between blacks and whites. Consequently, employers have a greater opportunity to hide sex discrimination behind a screen of seemingly legitimate practices. Such requirements are prohibited by the disparate impact doctrine, unless they are sufficiently job-related.

36. In disparate treatment cases, the Court has addressed this problem by adopting a complex allocation of burdens of proof and burdens of bringing forth evidence. See Texas Dep't of Community Affairs v. Burdine, 450 U.S. 248 (1981); McDonnell Douglas Corp. v. Green, 411 U.S. 792 (1973); Mendez, Presumptions of Discriminatory Motives in Title VII Disparate Treatment Cases, 32 STAN. L. REv. 1129 (1980).

37. Griggs v. Duke Power Co., 401 U.S. 424, 430 (1971) (the purpose of Title VII is to achieve equal employment opportunity and remove past barriers to such equality); McDonnell Douglas Corp. v. Green, 411 U.S. 792, 806 (1973) ("Griggs was rightly concerned that childhood deficiencies in the education and background of minority citizens, resulting from forces beyond their control, not be allowed to work a cumulative and invidious burden on such citizens for the remainder of their lives."). 
wages. ${ }^{38}$ A plaintiff usually cannot trace the cause of a wage disparity to a single purposeful discriminatory act. ${ }^{39}$ Because it looks only at the resulting harm, the impact doctrine does not require her to present an original "blameworthy" act.

Third, disparate impact doctrine facilitates the elimination of prejudice against women. ${ }^{40}$ Women are seen as less capable than men partly because they hold lower paying and less prestigious jobs; ${ }^{41}$ to the extent that Title VII reduces the gap in job prestige, it also reduces prejudice. ${ }^{42}$ Finally, eliminating the inequities which groups that historically have been victims of prejudice have suffered may be desirable in itself. ${ }^{43}$

Wage-impact claims do, of course, entail some economic costs to employers. An employment practice which disproportionately affects women's wages may, for a variety of reasons, be more efficient than any alternative means of setting pay. However, these inefficiency costs are not unique to wage-impact claims; all disparate impact claims involve similar potential inefficiencies. ${ }^{44}$ The courts,

38. See International Union of Elec. Workers v. Westinghouse Elec. Corp., 631 F.2d 1094, 1097 (3d Cir. 1980). One commentator has classified such claims as comparable worth claims based on perpetuation of past discrimination. Comment, supra note 11, at 1341-42.

39. See Brest, supra note 34, at 31-43. Moreover, even if the plaintiff could trace present impact to particular past discrimination, the defendant would probably not be responsible for that practice. See Griggs v. Duke Power Co., 401 U.S. 424, 430 (noting that one reason why blacks were less likely to pass Duke Power's tests was that they "have long received inferior education in segregated schools").

40. "[L]aws having a disproportionate impact aggravate the already especially disadvantaged and isolated positions of blacks in American Society, and that social position of blacks reinforces supremacist notions of 'inherent' white superiority, a superiority thought to explain and to justify the privileged social position of whites." Perry, supra note 30 , at 558 n.99. The same argument applies to the social positions of women in American society.

41. From a plaintiff's perspective, the inequality of roles perpetuates prejudices which stigmatize women. See Brest, supra note 34, at 35. From this "victim's" perspective, the fact that no one person can be blamed for the inequity is irrelevant. See Freeman, supra note 34, at 1052-57.

42. That society identifies certain jobs as "women's work" is not necessarily bad. The problem arises because society undervalues that work, and channels women into it. See Hearings On Job Segregation and Wage Discrimination Before the U.S. Equal Employment Opportunity Comm'n, 164-79 (1980) [hereinafter cited as EEOC Hearings] (testimony of Helen Hacker, Professor of Sociology, Adelphi Univ.); Blumrosen, supra note 11, at 402-28.

43. "The disproportionate absence of minorities from certain positions-whether or not itself the result of . . . discrimination-may conduce to discrimination in other areas." Brest, supra note 34 , at 43 . Greater social equality also has a number of indirect benefits. Equality may minimize costly social unrest. Yudof, Equal Educalional Opportunity and the Courts, 51 TEx. L. REV. 411, 456-64 (1973). Equality may appease those in the majority who have guilty consciences. Also, sex prejudice prevents the labor market from functioning efficiently, and thus reduces output of goods and services.

44. The disparate impact doctrine creates some economic inefficiency when it forces the 
recognizing these inefficiencies, have created the "business necessity" defense, which ensures that employers do not suffer too significant a hardship by allowing them to implement employment practices that are necessary to the maintenance of the business. ${ }^{45}$

Furthermore, wage-impact claims may encourage employers to adopt subjective wage-setting practices. Subjective standards make a prima facie case of disparate impact harder to establish because the disparate effects of particular standards are not readily identified. But this difficulty is also a general problem of disparate impact claims. ${ }^{46}$ Courts have reduced the incentive to adopt subjective stan-

employer to adopt practices that are less profitable than those he was using. Comment, The Business Necessily Defense To Disparate-Impact Liability Under Title VII, 46 U. CHI. L. REV. 911, 919 (1979). The disparate impact doctrine may nevertheless be efficient for society as a whole if social costs which otherwise would have flowed from the disparate results, see note 43 supra, exceed the efficiency loss due to giving up the practice.

45. The requirements of the business necessity defense are unclear. The defense was part of the Griggs opinion, which stated both that the questioned employment practice is unlawful if it "cannot be shown to be related to job performance," and that " $[\mathrm{t}]$ he touchstone is business necessity," Griggs v. Duke Power Co., 401 U.S. 424, 431 (1971). See also Dothard v. Rawlinson, 433 U.S. 321, 329, $331 \mathrm{n} .14$ (1977) (referring to both "a manifest relationship to the employment in question," and "necessary to safe and efficient job performance" as standards for permitting the employment practice) (emphasis added).

The lower courts have traditionally applied the apparently stricter business necessity standard. See United States v. Jacksonville Terminal Co., 451 F.2d 418, 451 (5th Cir. 1971) (the defendant must demonstrate that no "feasible or practical" alternative to the practice exists), cert. denied, 406 U.S. 906 (1972); United States v. Bethlehem Steel Corp., 446 F.2d 652, 662 (2d Cir. 1971) (business necessity defense requires an "irresistible demand"). Some courts have intimated that a balancing test applies, see, e.g., Robinson v. Lorillard Corp., 444 F.2d 791, 798 (4th Cir. 1971) ("the business purpose must be sufficiently compelling to override" the disparate impact), but the balance is weighted heavily against the employer.

The standard has recently shifted toward a less stringent job-relation test. The Supreme Court, in New York City Transit Auth. v. Beazer, 440 U.S. 568, 587 \& n.31 (1979), required only that safety and efficiency be "significantly served" by the defendant's policy against hiring methadone users. The Court did not elaborate on the standard by which courts should decide when employers' legitimate goals are "significantly served." Two circuit courts have since applied a similar standard. Contreras v. City of Los Angeles, 656 F.2d 1267, 1280 (9th Cir. 1981) ("significantly correlated with important elements of work behavior"); Chrisner v. Complete Auto Transit, Inc., 645 F.2d 1251, 1262 (6th Cir. 1981) ("substantially promote the proficient operation of the business").

For an overview of the business necessity defense, see Note, Business Necessity Under Tille VII of the Civil Rights Act of 1964: A No-Allemative Approach, 84 YALE L.J. 98 (1974); Comment, supra note 44.

46. A subjective scheme hides the factors an employer uses to make his decisions. In that way, subjective standards make more difficult the plaintiff's task of identifying factors which disproportionately affect women. See Heagney v. University of Wash., 642 F.2d 1157 (9th Cir. 1981) (requiring a plaintiff to identify an "objective" factor to make out a disparate impact claim).

Subjective schemes also make disparate treatment more difficult to prove. For example, cases concerning college professors demonstrate that use of subjective criteria may result in defendants routinely winning judgments. See, e.g., Johnson v. University of Pittsburgh, $435 \mathrm{~F}$. 
dards by giving these standards little weight as a defense to a prima facie case. ${ }^{47}$

In sum, wage-impact claims serve the same social goals and create the same problems as other disparate impact claims. Thus, as a policy matter, disparate impact doctrine should include sex-based wage discrimination claims.

\section{B. The Effect of the Fourth Equal Pay Act Defense on Wage-Impact Claims}

While policy considerations strongly favor allowing wage-impact claims, a literal interpretation of the fourth Equal Pay Act defense would bar such claims. To make a disparate impact claim, a plaintiff must identify a specific employment practice that, while facially neutral, affects employees in a gender-dependent manner. ${ }^{48}$ By invoking the impact doctrine, a plaintiff admits that a factor other than sex is the most direct cause of the wage differential. The employer may point to this factor and invoke the fourth defense.

Gunther provides some support for this interpretation of the fourth defense. ${ }^{49}$ After warning that the fourth defense "could have significant consequences for Title VII litigation," Justice Brennan noted that Title VII proscribes " not only overt discrimination but also practices that are fair in form, but discriminatory in operation.' . . . The fourth affirmative defense of the Equal Pay Act, however, . . . confine[s] the application of the Act to wage differentials attributable to

Supp. 1328, 1353-54 (W.D. Pa. 1977); Peters v. Middlebury College, 409 F. Supp. 857, 868 (D. Vt. 1976); Lewis v. Chicago State College, 299 F. Supp. 1357, 1359-60 (N.D. Ill. 1969). But see Sweeney v. Board of Trustees of Keene State College, 604 F.2d 106 (1st Cir. 1979) (woman professor proved she had been denied a promotion because of her sex), cert. denied, 444 U.S. 1045 (1980).

47. See, e.g., Harless v. Duck, 619 F.2d 611, 616-17 (6th Cir.) (interviewing procedure lacking objectivity cannot rebut a disparate impact showing), cert. denied, 449 U.S. 872 (1980); Brown v. Gaston County Dyeing Mach. Co., 457 F.2d 1377, 1382 (4th Cir. 1972) ("Elusive, purely subjective standards must give way to objectivity if statistical indicia of discrimination are to be refuted.").

48. A plaintiff may not merely show a disparity between an employer's work force and the local labor market without identifying a questionable employment practice. If the plaintiff cannot identify a facially neutral practice, she must proceed under the disparate treatment doctrine. See Heagney v. University of Wash., 642 F.2d 1157, 1163 (9th Cir. 1981).

49. At least one commentator reads Gunther as conclusively denying a wage-impact claim. See Gould, The Supreme Court's Labor and Employment Docket in the 1980 Term: Justice Brennan's Term, 53 U. CoLO. L. REV. 1, 66 (1981) ("The critical thrust of Justice Brennan's opinion was that the Griggs theory of liability, i.e., no intent necessary for a violation, could not be used in sex-based wage discrimination cases under either Title VII or the Equal Pay Act.").

50. Gunther v. County of Washington, 452 U.S. 161, 170 (1981). 
sex discrimination." $" 51$

However, Gunther also stressed that Title VII should be construed to avoid denying a remedy to victims of employment discrimination, unless Congress clearly mandates otherwise..$^{52}$ This view of Title VII conflicts with a literal interpretation of the fourth defense, which would deny a remedy to many victims of sex-based wage discrimination. This conflict, and Gunther's explicit statement that it did "not decide ... how sex-based wage discrimination under Title VII should be structured to accommodate the fourth affirmative defense, ${ }^{\prime 33}$ weigh heavily against reading Gunther as adopting this literal interpretation. ${ }^{54}$

A better interpretion of the fourth defense would use judicial interpretation of the defense in Equal Pay Act cases as a guide to incorporating the defense into Title VII. ${ }^{55}$ The courts have held that defendants in Equal Pay Act cases bear the burden of proving that gender did not play a role in their wage decisions. ${ }^{56}$ Moreover, they have held that facially neutral practices that perpetuate past societal wage discrimination are not based on a "factor other than sex."

51. Id. (quoting Griggs v. Duke Power Co., 401 U.S. 424, 431 (1971)) (emphasis added).

52. Id. at 178.

53. Id. at 171.

54. In Kouba v. Allstate Ins. Co., 523 F. Supp. 148, 161 (E.D. Cal. 1981), the district court read Gunther as limiting "the application of the fourth affirmative defense to "bona fide job rating systems." "Id. at 161.

55. Two courts have applied the disparate impact doctrine to sex-based wage discrimination. In Wambheim v. J.C. Penney Co., 642 F.2d 362 (9th Cir. 1981), the court held that a medical insurance plan could violate Title VII because it provided an employee's spouse with benefits only if the employee earned more than the spouse. Wambheim, however, did not explicitly consider the effect of the fourth Equal Pay Act defense. In Kouba v. Allstate Ins. Co., 523 F. Supp. 148 (E.D. Cal. 1981), a district court held that use of salary in a prior job as a factor in setting wages did not satisfy the fourth defense because prior salary might reflect the effects of past discrimination. Although Kouba was an equal pay for equal work claim brought under Title VII, rather than a disparate impact claim, the court explicitly incorporated the disparate impact rationale into the fourth defense. Id. at 161.

56. See, e.g., Brennan v. Owensboro-Daviess County Hosp., 523 F.2d 1013, 1031 (6th Cir. 1975), cert. denied, 425 U.S. 973 (1976); Futran v. Ring Radio Co., 501 F. Supp. 734, 738-39 (N.D. Ga. 1980); Marshall v. J.C. Penney Co., 464 F. Supp. 1166, 1195 (N.D. Ohio 1979); see also Sullivan, The Equal Pay Act of 1963: Making and Breaking a Prima Facie Case, 31 ARK. L. REV. 545, 584 (1978).

57. See Corning Glass Works v. Brennan, 417 U.S. 188, 205 (1974) ("That the company took advantage of [a job market in which women would work for lower wages than men] may be understandable as a matter of economics, but its differential nevertheless became illegal once Congress enacted into law the principle of equal pay for equal work."); Marshall v. J.C. Penney Co., 464 F. Supp. 1166, 1195-96 (N.D. Ohio 1979) (the fourth Equal Pay Act defense "does not include. . . seemingly neutral factors which operate to perpetuate past discrimination.").

Coming Glass and Marshall both involve employers who previously had intentionally dis- 
And these cases may also require an employer to demonstrate that a legitimate business concern justifies the wage differential. ${ }^{58}$ Incorporating these judicially implied limits on the fourth defense into Title VII necessarily means that wage-impact claims should be permitted.

The Bennett Amendment was a "technical amendment" designed to prevent conflicts between Title VII and the Equal Pay Act. ${ }^{59}$ Judicial gloss on the fourth defense, in Equal Pay Act cases, limits the scope of the defense. Similarly limiting the defense in Title VII cases furthers both the broad remedial purposes of Title VII and the conflict-avoidance purpose of the Bennett Amendment.

The only problem with this interpretation is that the Equal Pay Act cases have not clearly articulated the nexus between the business concern and the wage differential that will satisfy the fourth defense. ${ }^{60}$ The Title VII "business necessity" defense, however, already provides a readily available standard which is roughly consistent with the interpretation of the fourth defense in Equal Pay Act

criminated against women-hence their language may be dicta as applied to practices that perpetuate societal discrimination. But the reasoning of the cases does not distinguish between past discrimination by the employer and past societal discrimination. See Kouba v. Allstate Ins. Co., 523 F. Supp. 148, 161 (E.D. Cal. 1981).

58. See Strecker v. Grand Forks County Social Servs. Bd., 640 F.2d 96, 104 (8th Cir. 1980) (en banc) (Heaney, J., dissenting) (once a plaintiff shows equal pay for equal work, the employer must prove that "the education and experience requirements for the classification in question are reasonably related to the job duties to be performed'); id. at 100 (majority opinion) (agreeing with the dissent about the job-relation requirement, but finding that the requirement was met); EEOC v. Aetna Ins. Co., 616 F.2d 719, 726 (4th Cir. 1980) (pay differential based on an employee's experience and background is justified where the employer has a business need for a worker with that experience and background); Horner v. Mary Inst., 613 F.2d 706, 714 (8th Cir. 1980) (an employer may pay an unequal salary for equal work to attract a particular employee whose experience and ability made him the best person for the job); Schultz v. Wheaton Glass Co., 421 F.2d 259, 264 (3d Cir.) (to justify a wage disparity under the fourth Equal Pay Act defense based on greater flexibility of male employees, an employer must use that flexibility), cert. denied, 398 U.S. 905 (1970). The Equal Employment Opportunity Commission takes the similar position that a "payment plan which establishes separate and different 'male rates' and 'female rates' without regard to job content will be carefully examined." 29 C.F.R. $\$ 800.142$ (1981) (emphasis added).

The job relation of factors used to set wages is, to some extent, automatically built into the equal work requirement of the Equal Pay Act. See 29 C.F.R. $§ 800.125$ (1981) ("Possession of a skill not needed to meet requirements of the job cannot be considered in making a determination regarding equality of skill.")

59. See note 24 supra.

60. Compare Strecker v. Grand Forks County Social Servs. Bd., 640 F.2d 96, 100 (8th Cir. 1980) (holding that an employer's pay plan, which accounted for education and experience related to the job, satisfied the fourth defense) with Futran v. Ring Radio Co., $501 \mathrm{~F}$. Supp. 734, 739 (N.D. Ga. 1980) (to satisfy the fourth defense, an employer must show that a talk show host's ability to generate revenues for a radio station explained the total wage differential in question). 
cases. ${ }^{61}$ The policy concerns that justify the defense-a balancing of the need to remedy sex discrimination against the inequity of imposing the costs of remedying societal discrimination on particular employers-apply equally to Title VII and Equal Pay Act cases. ${ }^{62}$ Therefore, courts can and should interpret the fourth defense-in both Title VII and Equal Pay Act cases-as equivalent to the Title VII business necessity defense. ${ }^{63}$

\section{Comparable Worth as Proof of Disparate Impact}

Although courts should allow wage-impact claims, whether proof of comparable worth should state such a claim is an entirely separate question. ${ }^{64}$ Prior to Gunther, courts summarily rejected disparate impact claims based on a comparison of job values. ${ }^{65}$ Gunther, which explicitly left undecided the viability of such claims, ${ }^{66}$ probably will encourage them. ${ }^{67}$

61. The business necessity defense is interpreted differently in different circuits. See note 45 supra and accompanying text. The doctrine surrounding this defense, however, is far more sophisticated than that surrounding the fourth Equal Pay Act defense. See Sullivan, supra note 56, at 584-85. See also Note, supra note 45, at 99-102; Comment, supra note 44, at 918-20.

62. Sullivan, supra note 56, at 584-87, has argued that the four affirmative Equal Pay Act defenses should encompass Title VII doctrine.

63. Under this interpretation, the Bennett Amendment seems mere surplusage-the fourth Equal Pay Act defense adds nothing to the substantive provisions of Title VII. This is a disfavored statutory construction. See United States v. Menasche, 348 U.S. 528, 538-39 (1955), as the Gunther Court intimated. 452 U.S. at 170-71. When the Bennett Amendment was adopted, however, Congress did not know how the courts would construe either the Equal Pay Act or Title VII. Thus, it was reasonable for Congress to mandate that courts allow the same affirmative defenses under both statutes. Although this interpretation adds no substantive provisions to Title VII, it does not treat the Bennett Amendment as superfluous. Id. at 171.

64. Several commentators have proposed framing comparable worth as wage-impact claims. See, e.g. , Blumrosen, supra note 11, at 459; Comment, Equal Pay for Comparable Work, 15 HARV. C.R.-C.L. L. REv. 475 (1980). These proposals ignore the requirements of the disparate impact doctrine. See note 69 infra.

65. See Lemons v. City \& County of Denver, 620 F.2d 228 (10th Cir.) (requiring proof of unequal pay for equal work under 42 U.S.C. $\$ 1983$ (1976)), cert. denied, 449 U.S. 888 (1980); Christensen v. Iowa, 563 F.2d 353 (8th Cir. 1977) (an employer's deviation from a job evaluation plan to account for market factors does not violate Title VID).

Courts hesitated to permit comparable worth suits because Congress had explicitly rejected a comparable work standard in favor of an equal work standard when it passed the Equal Pay Act. See 108 Cong. Rec. 14,767-68 (1962) (remarks of Reps. St. George and Zelenko). After'Gunther, the equal pay for equal work standard does not apply to Title VII. See note 24, supra and accompanying text. Hence, the rejection of "comparable work" in the Equal Pay Act should not affect Title VII litigation.

66. 452 U.S. at 166 ("We emphasize at the outset . . . [that r]espondent's claim is not based on the controversial concept of 'comparable worth' . . . . ") (footnote omitted).

67. See Note, In Pursuit of Wages Based on Job Value - Gunther v. County of Washington, 


\section{A. Comparable Worth and the Title VII Disparate Impact Doctrine}

All employers ultimately use market rates to set salaries. ${ }^{68}$ Plaintiffs may present comparable worth disparate impact claims by alleging that use of market rates is a specific employment practice that adversely affects women. ${ }^{69}$ Under comparable worth theories, plaintiffs could establish disparate impact by showing that the local market rate for their jobs is less than the rate implied by bona fide job evaluations. ${ }^{70}$ To buttress this claim, they could show that market rates generally tend to discount women's work, including their jobs, because of sex prejudice. ${ }^{71}$ This approach seems to formally satisfy

29 DE PAUL L. REV. 907, 930 (1980) (9th Circuit opinion in Gunther lends support to comparable worth claims.); Release of New Study on Comparable Worth, 108 LAB. REL. REP. (BNA) 10, 11 (1981) (statement by Nancy Perlman, chair of the National Committee on Pay Equity).

68. Market rates influence all attempts to establish job values. Even "objective" pay plans reflect market factors. These plans often explicitly account for the present value of jobs by basing evaluations on specified benchmark jobs. Even in systems derived from analyses that do not explicitly depend on benchmark jobs, the choice of compensable factors and the weights assigned to them must comport with society's notions of the relationships between wages for various jobs. See Hildebrand, The Market System, in COMPARABLE WORTH, Issues AND ALTERnATIVeS, supra note 11, at 88-89; Schwab, Job Evaluation and Pay Selling: Concepts and Practices, in COMPARABLE WORTH, Issues AND ALTERNATIVES, supra note 11, at 62-70.

69. Commentators present policy arguments for or against allowing comparable worth claims without considering legal constraints, except perhaps to point out that existing doctrine does not address the societal undervaluation of "women's work." See, e.g. , EEOC Hearings, supra note 42; COMPARABLE WORTH, IsSUES AND ALTERNATIVES, supra note 11 (a collection of essays on the premises and the potential impact of comparable worth theories); WOMEN, WORK, AND WAGES, supra note 11 (a report commissioned by the Equal Employment Opportunity Commission on the feasibility of a comparable worth standard).

Several recent pieces have attempted to fit the comparable worth theory, and protection against society systematically undervaluing "women's work," within Title VII doctrine. See, e.g. , Blumrosen, supra note 11 (concluding that a showing of sex segregation of jobs should establish a prima facie Title VII claim); Note, supra note 11 (Title VII should allow comparable worth claims, which an employer may rebut by showing that he used a bona fide job evaluation system to set wages); Comment, supra note 64 (a showing of unequal average salaries of male and female workers should establish a disparate impact claim). These pieces do not discuss how the policy considerations which comparable worth theories raise comport with those underlying Title VII. Moreover, they ignore some of the requirements of the disparate impact doctrine. In particular they neglect to discuss: (1) whether the fourth affirmative Equal Pay Act defense precludes a disparate impact claim of sex-based wage discrimination; (2) the requirement that a plaintiff pinpoint a particular employment practice which causes a wage disparity; and (3) the business necessity defense. Sce Gasaway, supra note 11 (raising similar questions but not attempting to answer them); Nelson, Opton \& Wilson, supra note 11 (a critique of the Blumrosen article which points out, among other things, her inexact reading of the requirements of the disparate impact doctrine).

70. See Note, supra note 11 , at $677 \&$ n. 108 (proposing a method by which a plaintiff can establish a prima facie comparable worth case).

71. A plaintiff may need only to show a tendency of a questioned employment practice to disadvantage women. Cf. Dothard v. Rawlinson, 433 U.S. 321, 330 (1977). Psychological experiments documenting that people value a job which they consider to be "women's work" 
the requirements for a prima facie disparate impact case. ${ }^{72}$

\section{Confict with requirements of the disparate impact doctrine.}

Comparable worth claims, however, ignore the balance that the disparate impact doctrine strikes. Inequality of results does not automatically trigger liability under the disparate impact doctrine. ${ }^{73}$ Rather, a plaintiff must identify a "well-defined objective employment practice"74 and prove that this practice causes a disparity between male and female employees' opportunities. ${ }^{75}$ This requirement assures that Title VII does not unduly restrict an employer's prerogative to operate his business in a nondiscriminatory manner. ${ }^{76}$ An employer, by avoiding practices which disproportionately disadvantage women, can free himself from the threat of Title VII litigation. Yet an employer can escape the threat of comparable worth litigation only by eradicating all sex-based inequality-by preferentially treating women.

less than a substantively identical male job would show such a tendency. See EEOC Hearings, supra note 42, at 151 (testimony of Ann Viviano, Instructor, Psychology Dep't, Pace Univ.) (work that women produce is evaluated lower than comparable male products).

72. The Supreme Court has stated that taking advantage of a job market which compensates women at a lower rate than men will not satisfy the fourth Equal Pay Act defense. Corning Glass Works v. Brennan, 417 U.S. 188, 205 (1974). This does not necessarily imply that a plaintiff may point to use of market factors as a violation of Title VII. Market rates may reflect attributes of the job itself which legitimately explain pay differences. Once the plaintiff proves equal work, this legitimate role for market factors vanishes. Outside of equal work, this legitimate role persists.

73. See Furnco Constr. Corp. v. Waters, 438 U.S. 567, 579 (1978) ("the obligation imposed by Title VII is to provide an equal opportunity for each applicant regardless of race, without regard to whether members of the applicant's race are already proportionately represented in the work force") (emphasis in original); International Bhd. of Teamsters v. United States, 431 U.S. 324, 339 n.20 (1977) (Title VII does not require that an employer's work force be racially balanced). Senator Case, addressing concerns that Title VII might coerce employers to lower hiring standards, stated that "Title VII would not require, and no court could read Title VII as requiring, an employer to lower or change occupational qualifications . . . simply because proportionately fewer Negroes than whites are able to meet them." 110 CONG. REC. 7246-47 (1964) (insertion into record).

74. Heagney v. University of Wash., 642 F.2d 1157, 1163 (9th Cir. 1981); see Adams v. Gaudet, 515 F. Supp. 1086, 1125 (W.D. La. 1981); Nelson, Opton \& Wilson, supra note 11 at 283-84 (an impact claim based on de facto job segregation proposes a "wholesale assault on [an] employer's wage structure" rather than an "impact analysis of a specific employer practice").

75. See Dothard v. Rawlinson, 433 U.S. 321,329 (1977) (a plaintiff has the initial burden of proving "a significant discriminatory pattern").

76. "[T] $]$ he causation requirement serves to distinguish from the totality of conditions that a victim perceives to be associated with discrimination those that the law will address." Freeman, supra note 34, at 1056; see also Eisenberg, Disproportionate Impact and Illicit Motive: Theories Of Constitutional Adjudication, 52 N.Y.U. L. REV. 36, 42-99 (1977) ("proximate cause" as basis for limits on disparate impact theory). 
Comparable worth theories therefore create a special threat of Title VII litigation for employers. A court's decision whether a wage disparity exists will necessarily be highly subjective and indeterminate. ${ }^{77}$ These subjective decisions determine the threshold of proof that a plaintiff must present to make out a prima facie case. ${ }^{78}$ The subjectivity of this threshold impairs an employer's ability to know what practices Title VII prohibits, and thus increases the threat of litigation. This is especially true in comparable worth litigation because the employer may not have adopted any practice that is particularly peculiar to his business.

Under disparate impact doctrine, once a plaintiff presents a prima facie case, the employer can invoke the business necessity defense and escape liability. ${ }^{79}$ To establish the defense, an employer must prove that his wage rates closely reflect the attributes of the jobs in question. But an employer's wage rates may reflect more than job related factors like skill, effort, and responsibility; they may reflect complex influences like labor-management relations, societal values, and individual employer or employee preferences. Moreover, even if job related factors were the sole wage determinants, these factors have no objective value independent of a market rate. ${ }^{80}$ Thus, most

77. In allowing a comparable worth claim, a court must choose between the plaintiff's posited job evaluations and the defendant's wages; there is no unique objective standard against which a court can compare the defendant's wages. The problem of subjectivity is widely recognized. See, e.g., WOMEN, WORK, AND WAGES, supra note 11, at 94 ("no universal standard of job worth exists, both because any definition of the 'relative worth' of jobs is in part a matter of values and because, even for a particular definition, problems of measurement are likely"); Hildebrand, The Market System, in CoMPaRABLe WORTH, Issues AND ALTERNATIVES, supra note 11, at 83 ("no 'value free' system of [job] evaluation has yet been shown to exist"); Release of New Study on Comparable Worth, 108 LAB. REL. REP. (BNA) 10, 10 (1981) (statement of Ann Miller, Professor of Sociology, Univ. of Pa., and chairperson of the committee which issued the National Academy of Science Report on comparable worth) ("nor do we see the possibility of developing [a standard of universal job worth] - such judgments are ultimately subjective"); $\oint$. Note, supra note 11 , at 674-75 (job evaluation methodology "assumes that ... the compensable elements of job content can be identified and measured").

Determining whether a well-defined employment practice causes a wage disparity would not require subjective evaluations. A court could merely compare the wages that would result without the practice with the employer's actual wages.

78. The subjective evaluations a court must make in comparable worth suits differ from those in disparate impact suits where the proof that a disparity exists always turns on objective statistical evidence. See note 31 supra. Thus, that courts frequently make subjective evaluations in Title VII litigation does not necessarily imply that such decisions are appropriate to establish comparable worth claims. But of. Note, supra note 11 , at 679,680 \& n.123 (complexity of comparable worth suits is not different from that of other Title VII suits, hence comparable worth suits should be permitted).

79. See notes 30-33 supra and accompanying text.

80. A job evaluation must assign weights to factors such as skill, effort, and responsibil- 
employers will be unable to invoke the business necessity defense in comparable worth litigation.

Because the business necessity defense fails, a comparable worth claim will require an employer either to raise wages for women's jobs or hire more women for higher paying men's jobs. ${ }^{81}$ Indeed, given the subjective nature of the comparable worth issue, an employer takes a substantial risk of liability unless he equalizes the average wages of men and women. Yet Title VII does not require preferential treatment of women. ${ }^{82}$ By permitting comparable worth claims, courts would effectively impose on employers the burden of preferential treatment, which Title VII explicitly refuses to impose.

\section{Conflict with wage determination policy.}

Comparable worth claims also require that job-value, as measured by skill, effort, and responsibility, and other job related factors, completely determine wages. ${ }^{83}$ This approach ignores several important influences on wages, and if applied, would conflict with Title VII policy. ${ }^{84}$

First, the requirement that job content determine job value totally discounts the influence of organized labor on pay scales. The strength of a labor union is not a job related factor, yet it certainly affects pay levels. ${ }^{85}$ Judicial and EEOC determinations of "objective" job worth, under a broad-based comparable worth theory, might undercut union ability to influence wages. ${ }^{86}$ Congress care-

ity, and then determine the extent to which a job entails each factor in order to "measure" job value. WOMEN, WORK, AND WAGES, supra note 11, at 75 . The assignments of weights to factors, and factors to jobs, involve normative judgments. Id. at 75-77.

81. See Freeman, supra note 34, at 1099 (If courts presumed a disproportionate impact whenever the average salaries of male and female employees differ, and applied the job-relation test in a strict manner, employers could escape liability only by raising women's salaries until, on the average, they equalled men's salaries). For a statement of the policy differences between disparate impact theory and affirmative action, see Perry, supra note 30 , at 561 .

82. Title VII provides that no employer shall be required to give preferential treatment "to any individual or to any group because of . . . sex . . . on account of [numerical] imbalance" between his employees and the general workforce. 42 U.S.C. $\S 2000 \mathrm{e}-2(\mathrm{j})$ (1976). Cf. United Steelworkers v. Weber, 443 U.S. 193 (1979) (clarifying that while Title VII does not require preferential treatment of blacks, it does not prohibit voluntary affirmative action programs).

83. See WOMEN, WORK, AND WAGES, supra note 11, at 24-42; Note, supra note 11, at 674-75.

84. Comparable worth theories do not account for influences of internal labor markets, the segmentation of the labor market, employer and employee preferences for job stability, and labor union concerns. See WOMEN, WORK, AND WAGES, supra note 11, at 44-52.

85. See id. at 31 n.18.

86. This does not mean that job evaluations can play no role in union shops. In fact, 
fully structured Title VII's provisions to preserve the nondiscriminatory influences of organized labor. ${ }^{87}$ Courts should not construe disparate impact doctrine to conflict with that specific congressional intent.

Comparable worth theories also discount the productivity that an employer derives from a job. That one job entails more skill, effort, and responsibility than another does not imply that its value to the employer must be greater as well. ${ }^{88}$ Yet a job's value to employers will affect the market rate. Moreover, current salary is only part of an employee's total compensation package. Objectively similar jobs may differ in nonpecuniary rewards, such as in personal satisfaction and in potential for future rewards through advancement. Finally, an employer's wage policy may reflect goals only tangentially related to a dollar measure of job content, such as minimizing the collective power of workers, providing incentives for workers to perform well, reducing turnover in certain key positions, and minimizing training costs. ${ }^{89}$ Comparable worth claims, because they require employers to set wages according to "job-related" factors alone, conflict with Congress's efforts to ensure that Title VII does not unduly infringe an employer's rights to run a business in the manner which the employer believes is most efficient. ${ }^{90}$

unions often demand job evaluations as a means of facilitating the formation and administration of collective bargaining agreements. See Northrup, Wage Selling and Collective Bargaining, in COMPARABLE WORTH, Issues AND ALTERNATIVES, supra note 11, at 109-11. These job evaluations establish the relationships between the jobs in the shop; they do not establish an objective worth of jobs. Moreover, the subjective job values arrived at reflect structural features of labor markets, including union inputs. See WOMEN, WORK, AND WAGES, supra note 11 , at 47 .

87. The seniority defense, 42 U.S.C. $\$ 2000$ e-2(h) (1976), is the best example of non-jobrelated arrangements which Title VII was tailored to leave intact. Congress noted that union contracts often contained "last hired, first fired" provisions, and made clear that such provisions do not violate Title VII even where such a provision would result in dismissal of a disproportionate number of blacks. 110 CoNG. REC. 7217 (1964) (Sen. Clark responding to questions on Title VII). See, American Tobacco Co. v. Patterson, 50 U.S.L.W. 4364, 4367-68 (U.S. Apr. 6, 1982) (because Congress balanced labor and discrimination concerns when it passed Title VII, a seniority system which disparately affects blacks is not unlawful). Congress also explicitly rejected an amendment that would have prohibited discrimination against non-union members, even though it recognized that such discrimination might adversely affect blacks. See id. at 13,943-45 (1964).

88. Objectively determined job value would equal the going market wage rate in a perfectly competitive market. WOMEN, WORK, AND WAGES, supra note 11, at 44-45. Competition does not characterize actual labor markets, however, because of incomplete information, limitations on mobility, and institutional influences such as employer incentive programs. Id. at 45-47.

89. Id. at 46.

90. See County of Washington v. Gunther, 452 U.S. 161, 203 (1981) (Rehnquist, J., 


\section{B. A Proposed Standard for Wage Discrimination Review}

Despite the inconsistencies between comparable worth claims and Title VII doctrine, without these claims Title VII does not effectively address discrimination. Employers can discriminatorily assign values to jobs unless, of course, they explicitly use gender in assigning these values. ${ }^{91}$ Moreover, the undervaluation of female jobs in the market results, to some extent, from past discrimination, ${ }^{92}$ and the undervaluation of jobs that are universally perceived as "women's work" has a stigmatic effect similar to that which results from the undervaluation of an individual because she is female. ${ }^{93}$

To effectuate the remedial policies of Title VII, courts will have to address the pervasive problem of wage depression for "female jobs." The courts must adopt standards that comport with the policies which underlie Title VII. Although comparable worth impact claims advance the Title VII policies which the judicially created disparate impact doctrine serves, ${ }^{94}$ they intrude further into employer prerogatives and labor-management relations than Congress intended. To prevent such intrusion, courts must reject disparate impact claims based on job evaluations. ${ }^{95}$ Barring such claims eviscer-

dissenting) ("Congress balanced the need for a remedy for wage discrimination against its desire to avoid the burdens associated with governmental intervention into wage structures."); 2 H.R. REP. No. 914, 88th Cong., 1st Sess. 29 (1963) ("management prerogatives, and union freedoms ... [are] left undisturbed to the greatest extent possible'). See also United Steelworkers v. Weber, 443 U.S. 193, 206 (relying on fact that Title VII leaves management prerogatives intact to permit voluntary affirmative action plans).

91. See notes 19-28 supra and accompanying text.

92. See EEOC Hearings, supro note 42, at 202-03 (testimony of Phyllis Palmer, Research Associate, Business and Professional Women's Association) ("the low valuation of women's work may be due to ... [the fact] that men have been able to control public collective activities while women have been primarily responsible for single family domestic activities"); Blumrosen, supra note 11, at 418-19 (reviewing reports that "both sexes tend to value men and male characteristics, values, and activities more highly than those of women').

93. See, e.g. , EEOC Hearings, supra note 42, at 214-23 (testimony of Carolyn Reed, Executive Director, National Committee on Household Employment, National Urban League) (noting the stigma attached to household employment because it has traditionally been "women's work"); Brest, supra note 34, at 8.

94. Notes 34-43 supra and accompanying text discuss the purposes behind disparate impact doctrine. Comparable worth theory aims to remedy many of the same harms, albeit from another perspective. For example, the job market may channel women into lower paying jobs because women lack the requisite skills for higher paying positions. See EEOC Hearings, supra note 42, at 273-93 (testimony of Mary Corcoran, Associate Professor of Political Science, Univ. of Mich.). The disparate impact doctrine already prohibits an employer from demanding such skills unless the skills are a business necessity. The comparable worth theory, rather than remedying disparities in job composition, would increase the pay for the lower paying job.

95. Cf. Note, supra note 11 (implicitly proposing that an employer may use a bona fide 
ates the comparable worth approach. It does not, however, preclude use of job comparisons as evidence of intentional discrimination. ${ }^{96}$ The broad notion of intent that disparate treatment cases adoptwhere gross statistical disparities may create an inference of intentional discrimination ${ }^{97}$ - provides a flexible standard by which the courts can address the problem of depressed women's wages.

A comparison of job values which raises an inference that an employer intentionally discriminated does not require a court to impose wage scales on an employer. An employer's pay plan should reflect job content if all other factors remain constant. A discrepancy between job content and wages may indicate that gender prejudice influences an employer's wage decisions. As factors unrelated to job content become increasingly similar, the inference of intentional discrimination gets stronger. ${ }^{98}$ This inference arises not from a comparison of the employer's pay plan with an ideal pay plan, but rather from an internal discrepancy in an employer's pay plan. ${ }^{99}$ Hence, courts may infer intentional discrimination without restricting an employer's prerogative to structure pay plans in any nondiscriminatory fashion. ${ }^{100}$

job evaluation system in order to rebut a comparable worth claim under Title VII). This proposal eases the otherwise impossible burden the defendant faces in a comparable worth case. See notes 82-92 supra and accompanying text. But, like other proposed comparable worth approaches, this proposal would still require employers to set wages exclusively according to job related factors.

96. County of Washington v. Gunther, 452 U.S. 161 (1981), holds that job value comparisons may be evidence of intentional discrimination. The Court refused to state whether job value comparisons alone may establish a prima facie case. Id. at 166 n.8. The Court noted, however, the plaintiffs' contention "that the failure of the county to pay [them] the full evaluated worth of their jobs can be proven to be attributable to intentional sex discrimination." Id. at 181 (emphasis added). This suggests that the Court viewed job comparisons as constituting only partial evidence of intent to discriminate. Cf. Gunther v. County of Washington, 623 F.2d 1303, 1321 (9th Cir. 1979) (holding that job comparisons alone are insufficient to establish a prima facie Title VII case), $a f f d, 452$ U.S. 161 (1981).

97. Hazelwood School Dist. v. United States, 433 U.S. 299 (1977); International Bhd. of Teamsters v. United States, 431 U.S. 324, 335 n.15 (1977).

98. "Unequal pay for equal work" claims represent the case where the inference is greatest, since all factors, including job content, are equal.

99. Courts have begun to recognize claims under the disparate treatment doctrine which rely solely on evidence of inconsistencies in an employer's pay practices. See, e.g., Wilkens v. University of Houston, 654 F.2d 388, 406-07 (5th Cir. 1981), Taylor v. Charley Bros., 25 Fair Empl. Prac. Cas. (BNA) 602 (W.D. Pa. 1981); Greenspan v. Automobile Club of Mich., 495 F. Supp. 1021 (E.D. Mich. 1980). Gunther itself was a disparate treatment case based to a large degree on deviation of pay from the employer's job evaluation. See notes 21-23 supra and accompanying text.

100. Comparisons from which a court might infer intentional discrimination include: (1) comparisons between actual pay and an employer's own job evaluation; (2) comparisons which, independent of job evaluations, demonstrate that differences in jobs are not viewed by 


\section{Conclusion}

County of Washington $v$. Gunther held that a plaintiff may bring a Title VII sex-based wage discrimination claim without proving unequal pay for equal work. The Court, however, avoided the issues of whether sex-based wage discrimination claims can be brought under the disparate impact doctrine, and whether comparable worth suits are cognizable under that doctrine. This note has argued that courts should allow disparate impact claims but deny comparable worth claims. Comparison of job values, however, should be evidence from which courts can infer intentional discrimination. Interpreting Title VII in this manner will best further the social interests underlying wage discrimination law.

\section{Mark B. Seidenfeld}

the employer as justifying the wage differential; and (3) comparisons where the relationship beween jobs is universally accepted-the egregious cases. For example, if clerical supervisors (mostly female) were paid less than messengers (mostly male) whom they supervised, that would raise an inference of intentional discrimination.

Courts could decide how far the notion of inferred intent extends on a case-by-case basis. For example, if a plaintiff shows that an employer pays women less than men in comparable jobs, and that the job market is not clearing (i.e., the plaintiff's job is understaffed), a court could infer that the employer had intentionally discriminated by keeping wages for the plaintiff's job below the clearing wage. This appears to be the situation for nurses in San Jose, Cal. See $S$ J. nurses vote to strike at two more hospitals, San Jose Mercury News, Jan. 16, 1982, at 1, 20 col. 4. 


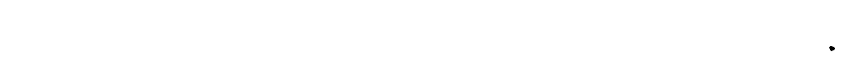

